\title{
Critical Analysis on Prevailing Teaching Strategies Promoting Critical Thinking in Public Elementary Classroom: A Survey of District Shaheed Benazirabad
}

\author{
Abdul Waheed Dahri * \\ MPhil Associate, Shaheed Benazir Bhutto University, Shaheed Benazirabad \\ Dr. Mehboob Ali Dehraj \\ Assistant Professor, Department of Education, Shaheed Benazir Bhutto University, Shaheed Benazirabad \\ Naseem Hyder Rajput \\ MPhil Associate, Shaheed Benazir Bhutto University, Shaheed Benazirabad \\ Masroor Hussain Abbasi \\ MPhil Associate, Shaheed Benazir Bhutto University, Shaheed Benazirabad
}

\begin{abstract}
Critical teaching is the process of students' intellectual development, which is used for conceptualization, communication, problem identification, collecting data through observation, analyzing information, and problemsolving and reflecting high-order thinking in the elementary classroom. The purpose of this study was to analyze the effective teaching strategy that promoted critical thinking among the students of public elementary schools in four Talukas of District Shaheed Benazirabad. A self-made questionnaire containing 15 statements was distributed among 102 participants including 64 male and 38 female teachers in 28 public elementary schools. The target population was 314 junior school teachers in 64 public elementary schools in the district. From the statistical data, it was analyzed, overall $82.35 \%$ of respondents found either strongly agree or agree and recommended the 'visualaid' teaching strategy promotes high order critical thinking in public elementary classrooms. 'Problem-based activity' and 'making charts on the topic' were also recommended as $68.72 \%$ and $64.70 \%$ respectively. From the findings it was analyzed that the visual aid teaching strategy observed as more effective and result oriented and was concluded that Visual-aid is widely integrating technology being used as a teaching tool to promote critical thinking and logics through colorful text, voice, pictures, and videos. The study is very important because it has dragged the teachers' attention toward the most effective and result-oriented teaching strategies.
\end{abstract}

Keywords: Critical thinking; teaching strategies; elementary students; classroom.

DOI: $10.7176 / \mathrm{JEP} / 11-12-14$

Publication date: April $30^{\text {th }} 2020$

\section{INTRODUCTION}

Critical Thinking

Critical thinking draws logical based conclusions, guides in emotional play to reach at conclusions. Human critical thinking is to make human efforts conscious, uncover biases and leads to conclusions. It uses open-mindedness to accept the evidences. The critical thinking believes cognitive efforts rather than blind beliefs. Teachers face challenges to promote critical thinking among their students by introducing innovative teaching strategies (Barnet, 2017).

\section{Prevailing Instructional Teaching Strategies Promoting Critical Thinking}

In the current scenario, education in Pakistan has suffered greatly from the lack of quality education and the inadequate implementation of adequate sources available at the basic level for education, so the capacity building of students is a challenge. In most of the public elementary classrooms, junior school teachers use traditional teaching methods that limit the productivity and critical thinking of students (Kazmi, 2005). Teachers are concerned about the completion of the work, instead of focusing on new ways of developing the thinking process. They focus mainly on structured grammatical models that focus strictly on bookish knowledge. Such an approach emphasizes the development of only reading and writing instead of thinking skills in the students. Most of the teachers use traditional teaching strategies for the memorization of text rather than promoting thinking critically (Rashid, 2017). The first language enables grade students to think more critically than the second language. Most of the teachers, deputed in the elementary schools even don't know about the student's psychology, only a few teachers can read students' minds; unfortunately, they don't have skills of such teaching strategies that can enhance student's creative thinking. Most of the students are not genius by birth but they are groomed by applying different teaching strategies in the elementary classroom. The majority of students even could not learn during their entire 
academic years in the schools. There is a lack of professional junior school teachers that activate and change such student's minds which could be able to think actively and participate in the classroom. Today, we are facing the 21 st century and this century is known as the century of inventions. In this century, education plays a very important role for learners. Critical thinking is very important to develop students' understandings, helps in observation, conceptualization, problem identification, information gathering, problem solution, reflection, decision-making and real-life problem solutions (Belecina, 2018). In the modern era of education, the teacher plays a vital role in actively involving the students in different activities to enable them to think critically in the classroom (Buehl, 2017). Teachers have a great challenge to create such an active learning environment in elementary education, which leads students to think critically for product acquisition. Critical thinking is designed to achieve the best results in any situation. This paper intends to analyze the effective teaching strategy that promotes high order critical thinking process among the elementary students. The purpose of analyzing an effective teaching strategy is to help the teachers developing critical thinking among students to get fruitful results and to know applicable teaching strategies in the classroom. Public elementary school level children are in the developing stage, and at this stage, critical thinking inculcation will be more effective, so the teacher needs to apply those strategies that inculcate critical thinking among the elementary students (Abrami et al., 2015).

\section{OBJECTIVES}

○ To investigate prevailing teaching strategies promoting critical thinking in elementary classroom.

- To analyze effective teaching strategy promoting high order critical thinking in the classroom.

\section{RESEARCH QUESTIONS}

○ What are the prevailing teaching strategies used in elementary classroom?

$\circ$ Which is the most effective teaching strategy promoting high order critical thinking in elementary classroom?

- Can students be encouraged to think critically?

\section{PROBLEM STATEMENT}

For the years in Pakistan, just traditional teaching methods have been used in schools instead of using methods focusing on the development of critical thinking skills. The junior school teacher lacks the ability to promote critical thinking in elementary classrooms so the students seem to be less rational and logical in critical thinking. Teachers use old teaching strategies because of effective training are rarely arranged by the authorities in the district. The concept of refining a child in schools has remained a challenge for the years. Teachers are sticking to their salaried-jobs instead of developing creativity among the elementary students though it's a divine profession.

\section{SIGNIFICANCE OF THE STUDY}

This study increases the students' interest in elementary classroom and furnishes thinking skills by transmitting effective knowledge in classroom. The approach facilitates exploring inspired transferable teaching methodology for improving classroom situations as compared to previous experiences. It is to be investigated and analyzed the effective strategy that promotes critical thinking and capabilities of students. This strategy will benefit the students, junior school teachers and the policymakers.

\section{SCOPE OF RESEARCH STUDY}

The study is so vast in its nature because it will save the time of teachers by choosing effective strategy among the prevailing strategies. By applying effective teaching strategy a teacher can get more results and also inculcate critical thinking among the young generation because they are the future assets.

\section{LITERATURE REVIEW}

Educationists and researchers have still been struggling to investigate innovative teaching strategies to improve thinking among elementary students. Problem based teachings have played significant role by implemented variety of teaching techniques that promote critical thinking in classroom. Technological tool assisted learning have facilitated effective teaching-learning both in public and private schools.

Rashid \& Qaisar (2017) stated in a case study about scheme based experiments, taking elementary students as a sample. Samples were taken in the form of visual aid (i.e. audio and video), questionnaire and field notes. The results calculated using the dialogues of the students during the interaction of teacher and student in the classroom by comparing the results before and after the investigation of the questionnaire. The post test results found higher than pre test. In the Pakistani context, this method is considered more authentic and effective to encourage critical thinking.

Vieira (2016) found that critical thinking and scientific literacy are the basic terms in science related education that enforces elementary students to think critically in the classroom. Science and technology has played main role 
to trigger students' needs in engaging in learning, building knowledge, thinking skills, developing values and thinking abilities in newly integrated ways. The study focused on learning experiences of grade 6, had very significant effect on elementary school science students' critical thinking and scientific literacy. This practice supported students' critical thinking and scientific literacy among students by implementing practical aid teaching approach.

Griffin (2014) concluded that teaching strategies can develop more critical thinking when teachers create a good thinking environment in the classroom, students can solve problems, share opinions, work together and communicate with each other.

Asari (2013) presented ideas for the development of critical thinking. Finalized different ideas including (1) determined a method for thinking reasons, suggestions for improving the weaknesses of any problem, (2) suggest a method to present substitute ideas, (3) at every stage using a problem/project-based learning and (4) modeling the behavior of a critical thinker from a teacher in the elementary classrooms.

Collier (2002) conducted studies in various primary schools; references have shown the usefulness of implementing various teaching strategies to promote important thinking in young children. It shows that students can develop critically thinking skills if teachers apply an environment that helps in thinking developing activities. Anderson (2002) conducted research based on child's development; it depicts the maturity of execution domains. Attention control seems to develop in childhood and develops rapidly at an early age. In contrast, cognitive flexibility, goal setting, and information processing experienced a critical developmental period of 7 to 9 years and were comparatively mature at 12 years of age. It is assumed that the transition period begins at the beginning of puberty and is likely to be shortly after "executive control". To validate our current understanding of executive function development and further to improve our understanding of the relationship between brain behaviors, longitudinal studies, including structural and functional neuroimaging, are needed.

Piaget (1952) stated in terms of cognitive development; the thinking process is one of the most important skills to develop in preschool children. Each new situation becomes an opportunity for young children to assimilate and manage information to create new conceptual structures.

\section{OPERATIONALIZED DEFINITIONS OF PREVAILING TEACHING STRATEGIES}

USED IN CLASSROOMS (1-5)

\begin{tabular}{|c|c|c|}
\hline S.No & Instructional Teaching Strategies & Characteristics \\
\hline 1 & $\begin{array}{l}\text { Appreciating students on questions- } \\
\text { answers }\end{array}$ & $\begin{array}{l}\text { Students are appreciated for answers on questions } \\
\text { asked by teacher. }\end{array}$ \\
\hline 2 & $\begin{array}{l}\text { Showing pictures and objects for } \\
\text { the description }\end{array}$ & $\begin{array}{l}\text { Students think critically about seen pictures and } \\
\text { objects and can describe easily in their own words. }\end{array}$ \\
\hline 3 & Visual-Aid & $\begin{array}{l}\text { Visual aid improves deeper understanding in the } \\
\text { form of colored text, voice and video. Multimedia } \\
\text { promotes thinking. }\end{array}$ \\
\hline 4 & Memorize new words from the text & $\begin{array}{l}\text { Increases vocabulary. Students can communicate } \\
\text { by reading, writing and speaking. }\end{array}$ \\
\hline 5 & $\begin{array}{l}\text { Understand the text and make } \\
\text { possible questions in first language }\end{array}$ & $\begin{array}{l}\text { Teacher provides a paragraph and asks student to } \\
\text { make possible questions as he can in the first } \\
\text { language. Student understands the paragraph and } \\
\text { makes a number of the question from given text. }\end{array}$ \\
\hline
\end{tabular}




\section{OPERATIONALIZED DEFINITIONS OF PREVAILING TEACHING STRATEGIES USED IN CLASSROOMS (6-10)}

\begin{tabular}{|c|c|c|}
\hline & Instructional Teaching Strategies & Characteristics \\
\hline 6 & Debating on the topic & $\begin{array}{l}\text { Improves public dealing, critical thinking, } \\
\text { information getting and self confidence. }\end{array}$ \\
\hline 7 & Problem-based activity & $\begin{array}{l}\text { Engages student in working independently, } \\
\text { improves critical thinking, involves in active } \\
\text { participation and helps in problem solution. }\end{array}$ \\
\hline 8 & Repeat lines to create ideas & $\begin{array}{l}\text { Helps the student to construct the sentences, } \\
\text { improves speed and brain connections. }\end{array}$ \\
\hline 9 & Making charts on the topics & $\begin{array}{l}\text { Improves students' behavior, keeping busy in } \\
\text { activity, makes positive classroom environment } \\
\text { and builds confidence. }\end{array}$ \\
\hline 10 & Group Discussion & $\begin{array}{l}\text { Improves communication skills, collaborative } \\
\text { learning, improves thinking skills and sharing } \\
\text { experiences. }\end{array}$ \\
\hline
\end{tabular}

OPERATIONALIZED DEFINITIONS OF PREVAILING TEACHING STRATEGIES USED IN CLASSROOMS (11-15)

\begin{tabular}{|c|c|c|}
\hline & Instructional Teaching Strategies & Characteristics \\
\hline 11 & $\begin{array}{l}\text { Focusing on text written on the } \\
\text { white board }\end{array}$ & $\begin{array}{l}\text { Engages student to the presentation of the content. } \\
\text { Improves students' attention to the main points } \\
\text { with different colors. }\end{array}$ \\
\hline 12 & Chalkboard & $\begin{array}{l}\text { Common traditional method applied in the public } \\
\text { schools. Cheapest learning }\end{array}$ \\
\hline 13 & Making fair copies & $\begin{array}{l}\text { Keeps student in discipline maintained, develops } \\
\text { reading and writing skills. }\end{array}$ \\
\hline 14 & Writing own word stories & $\begin{array}{l}\text { Improves students' self expression, critical } \\
\text { thinking, improves confidence and writing skills. }\end{array}$ \\
\hline 15 & $\begin{array}{l}\text { Focusing on the exercises given in } \\
\text { the text book }\end{array}$ & $\begin{array}{l}\text { It is the most important activity for the analysis of } \\
\text { the text lesson. This strategy helps student for } \\
\text { quick memorization of key points of lesson. }\end{array}$ \\
\hline
\end{tabular}

\section{STUDY DESIGN AND METHODOLOGY}

This study is quantitative in nature and survey approach was used. Self-made questionnaire was distributed to collect data from the participants. The research design leads the researcher to explore the teaching strategy promoting high order critical thinking in elementary classroom. The student's way of thinking is changed cognitively to study the productivity of this involvement. 


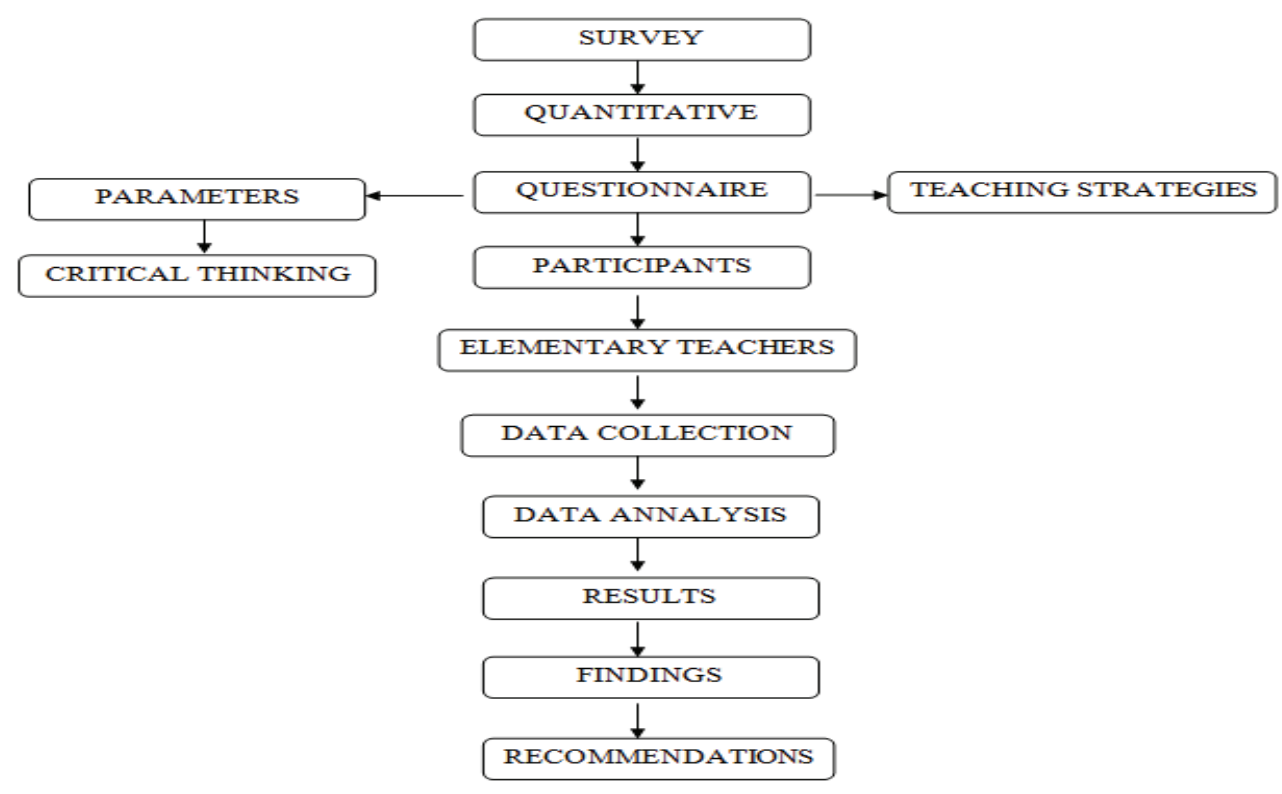

\section{Sample and Population}

The population comprised on 314 male and female junior school teachers in 64 public elementary schools. A sample of 102 participants including 64 male and 38 female, were randomly selected from the population including 201 male and 113 female teachers from 28 schools. All the randomly selected respondents from four talukas of district Shaheed Benazirabad were having more than five years of teaching experience in public elementary schools.

\section{Data Collection and Instrumentation}

Researcher personally traveled to the public elementary schools of four Talukas of district Shaheed Benazirabad where he obtained permission from the headmaster/mistress/in-charge of the schools and distributed Likert based questionnaire as an instrumentation to collect data from respondents. The questionnaire was distributed among both male and female teachers. The rate of participation from the respondents was $100 \%$.

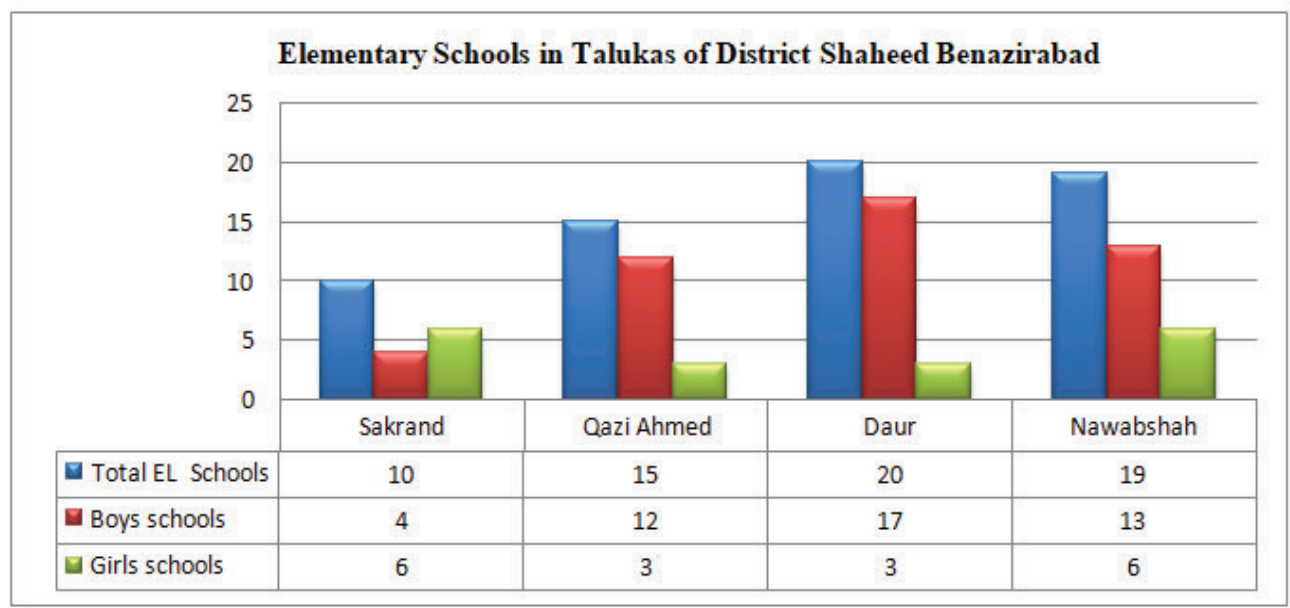

Figure 1 Public Elementary Schools

In Figure 1, the graph shows total number of public elementary schools in the individual talukas of district Shaheed Benazirabad. Total public elementary schools in the district were observed as 64 , in which boys schools were 46 whereas, total girls elementary schools in the district were 18 . 


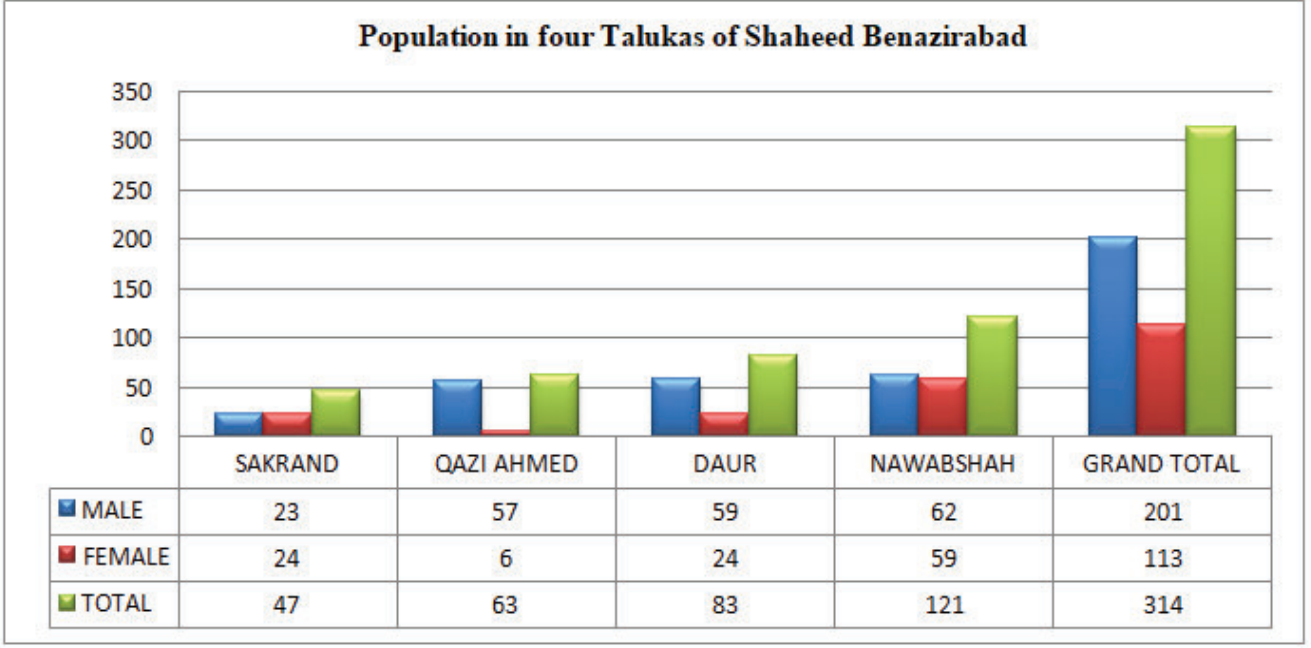

Figure 2 Population

In Figure 2, the graph shows the total population of four talukas of district Shaheed Benazirabad. Overall population in district was 314, including 201 male teachers and 113 female teachers in the district. In Sakrand, either male or female were observed 47 whereas, in Qazi Ahmed either male or female were observed 63 while in Nawabshah the population, either male or female were observed as 121 and in taluka Daur either male or female teachers observed as 83 .

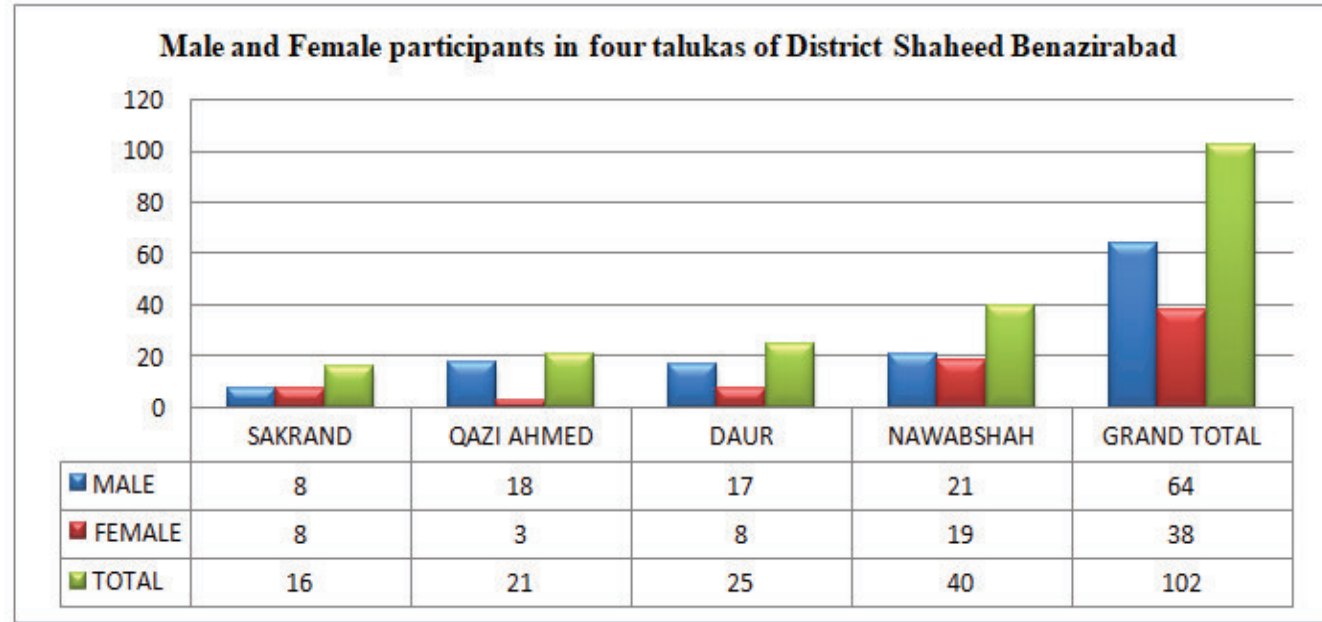

Figure 3 Participants

In Figure 3, the graphical representation shows total number of male and female respondents participated in survey in district Shaheed Benazirabad. Overall 102 respondents participated in survey including 64 male and 38 female. From taluka Sakrand, 16 respondents, either male or female participated. 21 respondents either male or female participated from taluka Qazi Ahmed, whereas 25 respondents either male or female participated from taluka Daur and total 40 respondents either male or female participated in taluka Nawabshah. 


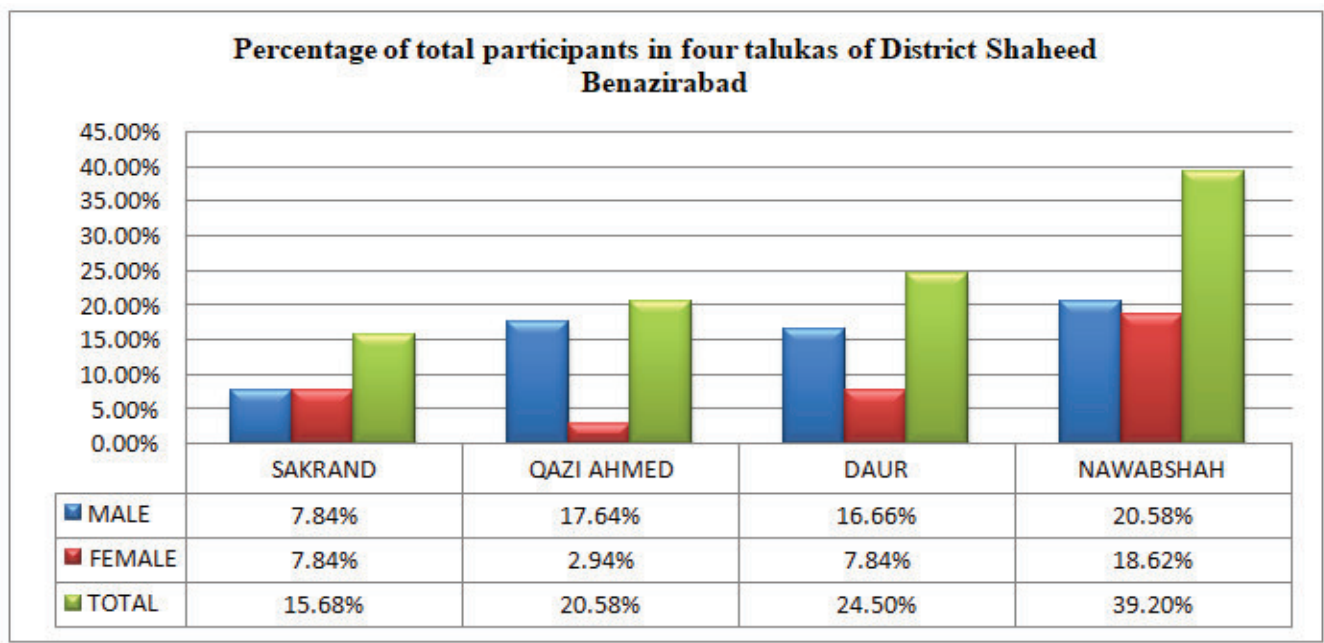

Figure 4 Percentage distributions of participants

In Figure 4, graph shows the total percentage of respondents participated from the four talukas of district Shaheed Benazirabad. It was observed from the statistical data, $15.68 \%$ either male or female respondents participated in taluka Sakrand, $20.58 \%$ of respondents, either male or female participated in taluka Qazi Ahmed whereas, $24.50 \%$ of respondents, either male or female participated in taluka Daur and $39.20 \%$ either male or female respondents participated in taluka Nawabshah.

\section{RESPONSES TO STATEMENTS SHOWING PERCENTAGE DISTRIBUTION}

Five point rating scale contributes series of statements to measure the attitudinal scale (Boone, 2012). It is the measured response from the people participated in the survey containing a series of questions on the topic (McLeod, 2008).

\section{RESULTS AND DISCUSSION}

The questionnaire displays the percentage of responses to the statements. Each questionnaire comprising 15 items was responded by 102 participants with five point rating scale as strongly disagree, disagree, neutral, agree and strongly agree in the favor of enlisted prevailing teaching strategies. The purpose of the study was to investigate effective teaching strategy promoting high order critical thinking among the students of public elementary schools in District Shaheed Benazirabad.

\begin{tabular}{|c|c|c|c|c|c|c|}
\hline & & $\begin{array}{l}\text { SAKR } \\
\text { AND }\end{array}$ & $\begin{array}{c}\text { QAZI } \\
\text { AHME } \\
\text { D }\end{array}$ & DAUR & $\begin{array}{c}\text { NAW } \\
\text { ABSH } \\
\text { AH }\end{array}$ & $\%$ \\
\hline \multirow{5}{*}{$\begin{array}{l}\text { 1. Appreciating } \\
\text { students on } \\
\text { questions- } \\
\text { answers }\end{array}$} & Strongly Disagree & $1.96 \%$ & $1.96 \%$ & $3.92 \%$ & $2.94 \%$ & $10.78 \%$ \\
\hline & Disagree & $4.90 \%$ & $3.92 \%$ & $4.90 \%$ & $7.84 \%$ & $21.57 \%$ \\
\hline & Neutral & $1.96 \%$ & 0 & $1.96 \%$ & $0.98 \%$ & $4.90 \%$ \\
\hline & Agree & $3.92 \%$ & $7.84 \%$ & $8.82 \%$ & $17.65 \%$ & $38.23 \%$ \\
\hline & Strongly Agree & $2.94 \%$ & $6.86 \%$ & $4.90 \%$ & $9.80 \%$ & $24.51 \%$ \\
\hline \multirow{5}{*}{$\begin{array}{l}\text { 2. Showing } \\
\text { pictures and } \\
\text { objects for the } \\
\text { description }\end{array}$} & Strongly Disagree & $3.92 \%$ & $2.94 \%$ & $4.90 \%$ & $3.92 \%$ & $15.68 \%$ \\
\hline & Disagree & $2.94 \%$ & $2.94 \%$ & $3.92 \%$ & $6.86 \%$ & $16.66 \%$ \\
\hline & Neutral & 0 & 0 & $0.98 \%$ & 0 & $0.98 \%$ \\
\hline & Agree & $5.88 \%$ & $8.82 \%$ & $10.78 \%$ & $19.60 \%$ & $45.10 \%$ \\
\hline & Strongly Agree & $2.94 \%$ & $5.88 \%$ & $3.92 \%$ & $8.82 \%$ & $21.57 \%$ \\
\hline \multirow[t]{5}{*}{ 3. Visual Aid } & Strongly Disagree & $1.96 \%$ & $0.98 \%$ & $1.96 \%$ & $1.96 \%$ & $6.68 \%$ \\
\hline & Disagree & $1.96 \%$ & $1.96 \%$ & $3.92 \%$ & $2.94 \%$ & $10.78 \%$ \\
\hline & Neutral & 0 & 0 & 0 & 0 & 0 \\
\hline & Agree & $3.92 \%$ & $2.94 \%$ & $3.92 \%$ & $5.88 \%$ & $16.66 \%$ \\
\hline & Strongly Agree & $7.84 \%$ & $14.71 \%$ & $14.71 \%$ & $28.43 \%$ & $65.69 \%$ \\
\hline \multirow{5}{*}{$\begin{array}{l}\text { 4. Memorize } \\
\text { new words } \\
\text { from the text }\end{array}$} & Strongly Disagree & $3.92 \%$ & $2.94 \%$ & $5.88 \%$ & $4.90 \%$ & $17.65 \%$ \\
\hline & Disagree & $6.86 \%$ & $7.84 \%$ & $11.76 \%$ & 15.68 & $42.15 \%$ \\
\hline & Neutral & 0 & 0 & $0.98 \%$ & $0.98 \%$ & $1.96 \%$ \\
\hline & Agree & $2.94 \%$ & $4.90 \%$ & $1.96 \%$ & $10.78 \%$ & $20.59 \%$ \\
\hline & Strongly Agree & $1.96 \%$ & $4.90 \%$ & $3.92 \%$ & $6.86 \%$ & $17.65 \%$ \\
\hline \multirow{5}{*}{$\begin{array}{l}\text { 5. Understand } \\
\text { the text and } \\
\text { make possible } \\
\text { questions in } \\
\text { L1 }\end{array}$} & Strongly Disagree & $3.92 \%$ & $1.96 \%$ & $4.90 \%$ & $2.94 \%$ & $13.72 \%$ \\
\hline & Disagree & $4.90 \%$ & $6.86 \%$ & $6.86 \%$ & $12.74 \%$ & $31.37 \%$ \\
\hline & Neutral & 0 & 0 & 0 & 0 & 0 \\
\hline & Agree & $4.90 \%$ & $6.86 \%$ & $9.80 \%$ & $18.63 \%$ & $40.19 \%$ \\
\hline & Strongly Agree & $1.96 \%$ & $4.90 \%$ & $2.94 \%$ & $4.90 \%$ & $14.70 \%$ \\
\hline
\end{tabular}

Table 1 Taluka wise percentage distribution in responses to 1-5 statements 
Table 1 shows the statistical data for percentage distribution on statements (1-5) responded by the participants on five point rating scale. The statement "Appreciating students on questions-answers" showed $62.74 \%$ of respondents either strongly agree or agree while $32.35 \%$ either strongly disagreed or disagreed and $4.90 \%$ respondents' undecided towards this prevailing strategy that promotes thinking in public elementary classroom. Most prevailing strategy in public elementary schools "Showing pictures and objects for the description", 66.67\% was average responded either strongly agree or agree while $32.34 \%$ was responded either strongly disagree or disagree. Majority of the participants found highly impacted towards most prevailing real-life and animated based "Visual-Aid" teaching strategy that promotes high order critical thinking, $82.35 \%$ of the respondents found either strongly agree or agree to this statement including $65.69 \%$ strongly agreed, $16.66 \%$ agreed while $17.64 \%$ either strongly disagreed or disagreed to this item. $38.24 \%$ of participants either strongly agreed or agreed to item "Memorize new words from the text" while $59.80 \%$ of respondents disagreed because this strategy doesn't help students to think critically though most of the junior school teachers use this strategy in elementary classroom. Some of elementary junior school teachers use "Understand the text and make possible questions in L1" in the classroom because it helps students feel free to make possible questions in the first language, $54.89 \%$ of the participants responded as either strongly agree or agree while $45.09 \%$ disagreed with this statement.

\begin{tabular}{|c|c|c|c|c|c|c|}
\hline \multirow{5}{*}{$\begin{array}{l}\text { 6. Debating on } \\
\text { the topic }\end{array}$} & Strongly Disagree & $5.88 \%$ & $2.94 \%$ & $7.84 \%$ & $7.84 \%$ & $24.51 \%$ \\
\hline & Disagree & $2.94 \%$ & $3.92 \%$ & $2.94 \%$ & $5.88 \%$ & $15.68 \%$ \\
\hline & Neutral & 0 & $0.98 \%$ & $0.98 \%$ & $1.96 \%$ & $3.92 \%$ \\
\hline & Agree & $1.96 \%$ & $2.94 \%$ & $5.88 \%$ & $4.90 \%$ & $15.68 \%$ \\
\hline & Strongly Agree & $4.90 \%$ & $9.80 \%$ & $6.86 \%$ & $18.63 \%$ & $40.19 \%$ \\
\hline \multirow{5}{*}{$\begin{array}{l}\text { 7. Problem- } \\
\text { based activity }\end{array}$} & Strongly Disagree & $3.92 \%$ & $1.96 \%$ & $4.90 \%$ & $2.94 \%$ & $13.72 \%$ \\
\hline & Disagree & $2.94 \%$ & $3.92 \%$ & $3.92 \%$ & $6.86 \%$ & $17.65 \%$ \\
\hline & Neutral & 0 & 0 & 0 & 0 & 0 \\
\hline & Agree & $5.88 \%$ & $7.84 \%$ & $10.78 \%$ & $19.60 \%$ & $44.11 \%$ \\
\hline & Strongly Agree & $2.94 \%$ & $6.86 \%$ & $4.90 \%$ & $9.80 \%$ & $24.51 \%$ \\
\hline \multirow{5}{*}{$\begin{array}{l}\text { 8. Repeat the } \\
\text { lines and } \\
\text { create ideas }\end{array}$} & Strongly Disagree & $6.86 \%$ & $5.88 \%$ & $9.80 \%$ & $10.78 \%$ & $33.33 \%$ \\
\hline & Disagree & $5.88 \%$ & $8.82 \%$ & $10.78 \%$ & $18.63 \%$ & $44.11 \%$ \\
\hline & Neutral & $0.98 \%$ & $0.98 \%$ & 0 & $1.96 \%$ & $3.92 \%$ \\
\hline & Agree & $0.98 \%$ & $1.96 \%$ & $2.94 \%$ & $4.90 \%$ & $10.78 \%$ \\
\hline & Strongly Agree & $0.98 \%$ & $2.94 \%$ & $0.98 \%$ & $2.94 \%$ & $7.84 \%$ \\
\hline \multirow{5}{*}{$\begin{array}{l}\text { 9. Making charts } \\
\text { on the topics }\end{array}$} & Strongly Disagree & $5.88 \%$ & $2.94 \%$ & $6.86 \%$ & $6.86 \%$ & $22.55 \%$ \\
\hline & Disagree & $0.98 \%$ & $2.94 \%$ & $2.94 \%$ & $3.92 \%$ & $10.78 \%$ \\
\hline & Neutral & $0.98 \%$ & 0 & 0 & $0.98 \%$ & $1.96 \%$ \\
\hline & Agree & $1.96 \%$ & $2.94 \%$ & $3.92 \%$ & $5.88 \%$ & $14.70 \%$ \\
\hline & Strongly Agree & $5.88 \%$ & $11.76 \%$ & $10.78 \%$ & $21.57 \%$ & $50 \%$ \\
\hline \multirow{5}{*}{$\begin{array}{l}\text { 10. Group } \\
\text { Discussion }\end{array}$} & Strongly Disagree & $3.92 \%$ & $2.94 \%$ & $4.90 \%$ & $3.92 \%$ & $15.68 \%$ \\
\hline & Disagree & $7.84 \%$ & $8.82 \%$ & $14.70 \%$ & $20.59 \%$ & $51.96 \%$ \\
\hline & Neutral & 0 & 0 & 0 & $0.98 \%$ & $0.98 \%$ \\
\hline & Agree & $2.94 \%$ & $5.88 \%$ & $3.92 \%$ & $10.78 \%$ & $23.53 \%$ \\
\hline & Strongly Agree & $0.98 \%$ & $2.94 \%$ & $0.98 \%$ & $2.94 \%$ & $7.84 \%$ \\
\hline
\end{tabular}

Table 2 Taluka wise percentage distribution in responses to 6-10 statements

Table 2 represents statistical data for the series of statements (6-10), whereas percentage distribution of four talukas of district is shown. In the responses to statement 6 , overall $55.87 \%$ of respondents agreed to prevailing item "Debating on the topic" that it promotes thinking skills in classroom while $40.19 \%$ either strongly disagreed or disagreed, just 3.92\% responded as undecided. The statement "Problem-based activity" has been used by teachers for thinking skills development in elementary schools while conducting a survey this strategy was responded $68.72 \%$ either strongly agree or agree and it was disagreed by $40.19 \%$ respondents, $3.92 \%$ found undecided for this statement. $18.62 \%$ of respondents found either strongly agree or agree in favor of the statement "Repeat lines to create ideas" while majority $77.44 \%$ of respondents rejected this strategy and just $3.92 \%$ of respondents found neutral.

In elementary classrooms, it is considered that "Making charts on the topics" develops critical thinking by self-made charts among students, $64.70 \%$ of respondents favored this strategy by either strongly agree or agree while $33.33 \%$ disagreed to this statement. "Group discussion" is considered as thinking development strategy by sharing an individual's ideas in classroom. Just 31.37\% responded either strongly agree or agree while most $67.64 \%$ responded disagreed with this prevailing teaching strategy at the elementary level. 


\begin{tabular}{|c|c|c|c|c|c|c|}
\hline \multirow{5}{*}{$\begin{array}{l}\text { 11. Focusing on } \\
\text { text written } \\
\text { on whiteboard }\end{array}$} & Strongly Disagree & $6.86 \%$ & $5.88 \%$ & $9.80 \%$ & $10.78 \%$ & $33.33 \%$ \\
\hline & Disagree & $6.86 \%$ & $8.82 \%$ & $10.78 \%$ & $20.59 \%$ & $47.06 \%$ \\
\hline & Neutral & 0 & $0.98 \%$ & 0 & $0.98 \%$ & $1.96 \%$ \\
\hline & Agree & $0.98 \%$ & $3.92 \%$ & $3.92 \%$ & $5.88 \%$ & $14.70 \%$ \\
\hline & Strongly Agree & $0.98 \%$ & $0.98 \%$ & 0 & $0.98 \%$ & $2.94 \%$ \\
\hline \multirow[t]{5}{*}{ 12. Chalkboard } & Strongly Disagree & $6.86 \%$ & $5.88 \%$ & $8.82 \%$ & $10.78 \%$ & $32.35 \%$ \\
\hline & Disagree & $3.92 \%$ & $3.92 \%$ & $7.84 \%$ & $9.80 \%$ & $25.49 \%$ \\
\hline & Neutral & 0 & 0 & 0 & 0 & 0 \\
\hline & Agree & $1.96 \%$ & $4.90 \%$ & $3.92 \%$ & $10.78 \%$ & $21.57 \%$ \\
\hline & Strongly Agree & $2.94 \%$ & $5.88 \%$ & $3.92 \%$ & $7.84 \%$ & $20.58 \%$ \\
\hline \multirow{5}{*}{$\begin{array}{l}\text { 13. Making Fair } \\
\text { copies }\end{array}$} & Strongly Disagree & $3.92 \%$ & $2.94 \%$ & $6.86 \%$ & $5.88 \%$ & $19.60 \%$ \\
\hline & Disagree & $6.86 \%$ & $8.82 \%$ & $11.76 \%$ & $16.66 \%$ & $44.11 \%$ \\
\hline & Neutral & $0.98 \%$ & 0 & $0.98 \%$ & 0 & $1.96 \%$ \\
\hline & Agree & $1.96 \%$ & $3.92 \%$ & $1.96 \%$ & $11.76 \%$ & $19.60 \%$ \\
\hline & Strongly Agree & $1.96 \%$ & $4.90 \%$ & $2.94 \%$ & $4.90 \%$ & $14.70 \%$ \\
\hline \multirow{5}{*}{$\begin{array}{l}\text { 14. Writing own- } \\
\text { word stories }\end{array}$} & Strongly Disagree & $3.92 \%$ & $1.96 \%$ & $4.90 \%$ & $3.92 \%$ & $14.70 \%$ \\
\hline & Disagree & $4.90 \%$ & $3.92 \%$ & $5.88 \%$ & $7.84 \%$ & $22.55 \%$ \\
\hline & Neutral & 0 & $0.98 \%$ & $0.98 \%$ & $1.96 \%$ & $3.92 \%$ \\
\hline & Agree & $1.96 \%$ & $4.90 \%$ & $6.86 \%$ & $7.84 \%$ & $21.56 \%$ \\
\hline & Strongly Agree & $4.90 \%$ & $8.82 \%$ & $5.88 \%$ & $17.65 \%$ & $37.25 \%$ \\
\hline \multirow{5}{*}{$\begin{array}{l}\text { 15. Focusing on } \\
\text { the exercises } \\
\text { given in the } \\
\text { text book }\end{array}$} & Strongly Disagree & $4.90 \%$ & $2.94 \%$ & $6.86 \%$ & $5.88 \%$ & $20.58 \%$ \\
\hline & Disagree & $7.84 \%$ & $11.76 \%$ & $13.72 \%$ & $25.49 \%$ & $58.82 \%$ \\
\hline & Neutral & 0 & 0 & 0 & 0 & 0 \\
\hline & Agree & $1.96 \%$ & $2.94 \%$ & $1.96 \%$ & $4.90 \%$ & $11.76 \%$ \\
\hline & Strongly Agree & $0.98 \%$ & $2.94 \%$ & $1.96 \%$ & $2.94 \%$ & $8.82 \%$ \\
\hline
\end{tabular}

Table 3 Taluka wise percentage distribution in responses to 11-15 statements

Table 3 represents the percentage distributions in responses to the statements (11-15). The whiteboard has remained students' center of attention for the years but at this stage the survey showed $80.39 \%$ of respondents either strongly disagree or disagree to "Focusing on text written on the white board" while just $17.64 \%$ agreed to this statement. The "Chalkboard", traditional teaching has been remained the most favorite teaching strategy in all public elementary schools but nowadays it is replaced by innovative teaching strategies. The survey showed just $42.15 \%$ of participants responded either strongly agree or agree while $57.84 \%$ responded as either strongly disagree or disagree with this traditional teaching strategy. The most prevailing strategy "Making fair copies" has been remained common in all elementary schools; this statement was agreed by $34.30 \%$ of respondents while $63.71 \%$ either strongly disagreed or disagreed. "Writing own word stories" develops thinking by collected ideas while writing own stories; the survey responses showed $58.81 \%$ either strongly agree or agree while $37.25 \%$ respondents disagreed with this item. The most prevailing teaching strategy "Focusing on the exercises given in the textbook" in almost all public elementary schools of the district was responded as $20.58 \%$ agreed while most $79.40 \%$ of participants responded as either strongly disagree or disagree.

\section{Findings of the study}

The findings show that teachers have rejected old teaching strategies by disagreeing with those statements which are no longer supported for the critical thinking development process among the students of public elementary schools. According to Table 1, the findings of statistical data resulted as $82.35 \%$ of respondents found overall agree and recommended 'visual-aid' teaching strategy that promotes high order critical thinking in public elementary classrooms. Whereas Table 2 showed the results for the statements 'Problem-based activity' and 'making charts on the topic' also strongly recommended by the respondents as $68.72 \%$ and $64.70 \%$ respectively.

\section{CONCLUSION}

Analysis of prevailing teaching strategies in the elementary classroom showed the significant impact on the respondents towards visual-aid teachings that promoted high order critical thinking. The survey conducted from the public elementary junior school teachers; resulted, $82.35 \%$ of respondents found highly influenced towards visual teachings. It was concluded that visual aid teachings made elementary classroom a realistic education; young children think for next by visualizing colored text, voice, pictures and videos, all influenced children's thinking and logic. The elementary students found very much attracted to moving pictures and objects that enhanced child's thinking capability. 


\section{RECOMMENDATIONS}

Visual-aid teaching promotes critical thinking than any other prevailing teaching strategy used in public elementary schools so it is recommended to install LED TV in classrooms through it is the best use for students of elementary classes. Teachers can personally arrange a flash drive that costs Rs.300 to Rs.500. It is easily accessible in the market. Through the pictures from Google, videos from Youtube, colorful text and variety of presentations on the related topic; junior school teachers can develop critical thinking among young students. If any of the teachers don't have the internet facility at their home or workplace, they can easily get data on demand from the market. LED TV is available at lowest cost of 5000 PKR to 6000 PKR with 20 inches, can easily be managed from the School Management Committee (SMC) funds in Pakistan. Whereas SMC fund for each Government Public Elementary school is assigned 50,000 PKR per year. The funds assigned are utilized to maintain school infrastructure. Multimedia is an expensive tool; it costs from 15000 PKR to 20000 PKR per single item. The government has not sufficient funds to implement multimedia for visual aid teachings throughout the 64 elementary schools in the district Shaheed Benazirabad.

\section{REFERENCES}

Rashid, S., \& Qaisar, S. (2017). Role Play: A Productive Teaching Strategy to Promote Critical Thinking. Bulletin of Education and Research, 39(2), 197-213.

Belecina, R. R., \& Ocampo Jr, J. M. (2018). Effecting Change on Students' Critical Thinking in Problem Solving. EDUCARE, 10(2)

Barnet, S., Bedau, H. A., \& O'Hara, J. (2017). Critical thinking, reading, and writing: A brief guide to argument (p. 480). Bedford/St. Martin's.

Buehl, D. (2017). Classroom strategies for interactive learning. Stenhouse Publishers

Rashid, S., \& Qaisar, S. (December 2016). Developing Critical Thinking through Questioning Strategy among Fourth Grade Students. Bulletin of Education and Research, 153-168

Rashid, S., \& Qaisar, S. (December 2016). Developing Critical Thinking through Questioning Strategy among Fourth Grade Students. Bulletin of Education and Research, 153-168

León, J. M. (January-June 2015). A Baseline Study of Strategies to Promote Critical Thiniking in the PreSchool Classroom. Gist Education and Learning Research Journal , 113-127.

Abrami, P. C., Bernard, R. M., Borokhovski, E., Waddington, D. I., Wade, C. A., \& Persson, T. (2015). Strategies for teaching students to think critically: A meta-analysis. Review of Educational Research, 85(2), 275-314

Griffin, P., \& Care, E. (Eds.). (2014). Assessment and teaching of 21st century skills: Methods and approach. Springer

Asari, A. R. (2013). Ideas for Developing Critical Thinking at Primary School Level. ResearchGate.

Boone, H. N., \& Boone, D. A. (2012). Analyzing likert data. Journal of extension, 50(2), 1-5.

Hansen, B. (2009). 15 Teacher Shortages. Issues in K-12 Education: Selections From CQ Researcher, 329.

McLeod, S. A. (2008). Likert scale

Richmond, J. E. (2007). Bringing Critical Thinking to the Education of Developing Country Professionals. International education journal, 8(1), 1-29.

Sons, J.W. (2006). Development of Critical Thinking in Occupational Therapy students. Wiley InterScience, 4960.

Kazmi, S. W., \& Quran, H. (2005). Role of education in globalization: A case for Pakistan. SAARC journal of human resource development, 1(1), 90-107.

McDonald, L. (2004). Moving from reader response to critical reading: developing 1011 -year-olds' ability as analytical readers of literary texts. Literacy, 38(1), 17-25

Anderson, P. (2002). Assessment and development of executive function (EF) during childhood. Child neuropsychology, 8(2), 71-82.

Collier, K., Guenther, T., \& Veerman, C. (2002). Developing Critical Thinking Skills through a Variety of Instructional Strategies.

Akram, M. \& Mahmood, A. (2001). The need of communicative approach (in ELT) in program in teacher training Pakistan. Language in India, 11(5), 172-178.

Alexander, P. A., \& Judy, J. E. (1988). The interaction of domain-specific and strategic knowledge in academic performance. Review of Educational research, 58(4), 375-404 